\title{
Application of Communicative Language Teaching Approach in the Preparatory Program of Shaqra University, Saudi Arabia
}

\author{
Hatim Hassan Tawfiq \\ College of Sciences and Humanity Studies, Thadiq, Shaqra University, Saudi Arabia \\ Tel: 96-65-5616-4781 E-mail: hatim@su.edu.sa
}

Received: March 13, 2020

Accepted: May 15, 2020

Published: May 15, 2020

doi:10.5296/jse.v10i2.16982

URL: https://doi.org/10.5296/jse.v10i2.16982

\begin{abstract}
This study is based on communicative language teaching perceptions that learners have toward CLT communicatively based lectures at the preparatory program of Shaqra university. The Problem of concern is to assure that CLT approach is truly practiced. Presuppositions assumed are concerned with students' belief about efficiency of CLT approach to help acquiring an outstanding communicative competence when learning a new language and the lecturers' assumption that CLT is an ideal approach for teaching a new language. The study uses a questionnaire constructed to extract perceptions toward practices of CLT approach from students and lecturers. The Findings of the study show that students learn a new language effectively when it is used as a vehicle for doing something such as greeting, requesting, giving, and apologizing. Overall, students think that communication is an important skill and teachers have faith in CLT as a perfect approach enhancing students' communication skill. It is recommended in the study that teachers had better employ CLT approach to enhance communication and that students had better make communication main objective for learning a new language. The study suggests for further studies areas of controversial issues concerning priority of grammatical accuracy to communicative accuracy when learning a new language.
\end{abstract}

Keywords: Communicative, approach, language, teaching, learner 


\section{Introduction}

Communicative language teaching (CLT) is an approach of language teaching that focuses on acquiring a language first and foremost to communicate with others. Larsen -Freeman (2001) thinks that communication is a must in language learning and believes that language is for communication and in a communicative course; everything is done with a communicative concentration (Larsen-Freeman 2001). Communication comprises finding out about what people underwent on a holiday or on last weekend, and know something about friends' happiness, accomplishments, favorites, and feelings. It also contains clearing up everyday practices to other people that want to know, conversing contemporary dealings, making an electronic mail message with some private news, or expressing a remarkable book, an editorial or a podcast. It is stated in the hypotheses of this study that both lecturers and students perceive CLT as an ideal method allowing students to reach an outstanding proficient stage of communication.

\subsection{Statement of the Problem}

Students enrolled in the preparatory program of Shaqra university find it difficult to communicate in the target language and difficult to use it freely to express themselves. Students can read / apprehend a text; they are able to read and understand but the problem arises when asked to speak briefly about what has been read. The main problem of the research is that teachers of the preparatory year asserts the implementation of tenets and principles of CLT approach that mainly concentrate on communication but still there is a problem of communication among students. it has been noted that students' mastery of communication does not correspond with efforts and practices of CLT approach which focus mainly on communication. When teachers say that a specific syllabus is based on tenets of CLT, there are some communicative tenets should be taken into consideration. Such as accuracy and fluency, the relation between the student and the teacher, syllabus design, learning and acquisition, teaching and learning activities in CLT including communicative tasks, materials employed in teaching, classroom activities and typical communicative activities. Teachers and learners are involved in giving more explanation about all the tenets above. The study is concerned with searching for students' perception toward CLT. These perceptions include the actual tenets, principles and practices that distinguish classes of communicative language teaching approach. When teachers and learners precisely perceive these main communicative teaching points, then CLT implementation is fully and efficiently carried out.

\subsection{Research Questions}

The researcher addresses these questions in the study:

a) What attitudes do learners have toward CLT communicatively based lectures?

b) To what extend do teachers believe that CLT approach is ideal to teaching English language? c) What type of CLT strategies do teachers put into practice when teaching English language?

d) What problems in practicing CLT are highlighted by students and teachers?

\subsection{Significance of The Research}




\section{Mll Macrothink}

Journal of Studies in Education

ISSN 2162-6952

2020, Vol. 10, No. 2

The researcher strongly believes that the result of the study will provide information to English teachers, learners, curriculum designers, and researchers. It is the belief of the researcher that every language teacher, learner, and designer will benefit a lot of it. The researcher thinks that the study is significant because it searches for student's perceptions toward CLT approach. A matter that helps improving students' English communicative abilities appropriately in context as CLT comprises activities and teaching practices that develop communicative competence in authentic context. Understanding students' perception toward CLT helps finding and analyzing language teaching techniques that make learners able to engage in the pragmatic, authentic and functional uses of language for meaningful purposes. Most of the educational systems around the world shift from traditional teaching methods to the universal communicative teaching approach. English education in Saudi Arabia has come across a model shift from an emphasis on receptive skills, for instance, grammar and reading comprehension, to stress on productive skills, such as: speaking and writing. The major English language teaching method has altered from the outdated grammar-translation approach to communicative based English teaching.

\section{Literature review}

CLT approach emerges from the idea that communication is the ideal objective of acquiring a second language. This perfect point focuses at evolving students' communicative competence to acquire another language. Educators, in light of this conception, think that teachers would be advised to utilize communicative resources stressing the language expected to use and comprehend several types of roles. Larsen-Freeman (2001) thinks that communication is a must in language learning and believes that language is for communication and in a communicative course; everything is done with a communicative concentration. Students acquire language through communicative activities. Larsen-Freeman also notes that language games, for instance: card game, scrambled sentences, problem solving tasks, picture strip story, and role play activities that match the principles of the communicative approach are activated in a CLT classroom.

\subsection{The scope of Communicative Language Teaching Approach}

In observation to a class of adult immigrants to Canada, a teacher starts distributing handouts to his students. The handouts contain two sides. One side is a sports column from a recent newspaper in which the reporter discusses whom he thinks will win the world cup. The teacher asks his students to read and underline the reporter's prediction. All instructions are made in the target language. The teacher asks students to find out which country, according to the reporter's point of view, have a greater chance to win the world cup and which one has the lesser. He asks about students' predictions, too. Whenever there are some errors, neither the teacher nor the students pay attention to them. Then, the teacher asks students to go to the other side in which the same article is written but in haphazard way and students should unscramble it. After that, the teacher tells the students to play a game. He groups students into four groups and provides each picture. He explains each student's task. Students are to work out the images. There are important principles underlying the behaviors of the teacher in the observations of the class above. The first of these principles are the handouts, which are extracted from authentic language of the newspaper where language is used in the real context. The teacher tells the students to underline the reporter's predictions and to say which 
ones they think the reporter feels surest of and which he feels least sure of. When students are, able to figure out the writer's prediction that does meant he is communicatively competent. The teacher provides the students the directions for the activity in the target language.

In a communicative class, teachers provide students with models to use the language as much as they through communicative activities. There are many typical categorizations of activities in a communicative language classroom. Paulston and Bruder (1976), for example, in their book 'Teaching English as a Second Language, techniques and Procedures' categorized the activity types that they believed were of supreme advantage in empowering students to reach communicative competence into the four sorts below:

a) Social Formulas and Dialogs: These wrap speech happenstances as greetings, partings, introductions, excuses, compliments, complaints, hiding feelings, etc. It is actually difficult to lie, to criticize and to turn someone down for a date in another language, and the learners of a foreign language need to be taught how to get along with those situations in an appropriate manner (Paulston \& Bruder, 1976).

b) Community Oriented Tasks: Those are sets of exercises, which compel the student to interact with native speakers outside the classroom.

c) Problem-Solving Activities: The students are presented with a problem and some alternative solutions, from among which they have to choose one or create their own.

d) Role Plays: In role-plays, students are assigned a fictitious role. The students even act out the role of themselves. The simplicity of role-plays and the improvisation is a matter of student proficiency.

Paulston and Bruder (1976) maintain that the teacher should attach importance to the format of the role play which consists of three basic components, being a complex one or not. In the situation, the teacher clearly explains the scene and the plot of the role play, which is followed by the description of the task and the action to be accomplished. Then, the teacher assigns the roles, the list of characters, making sure that the roles are not too elaborate for the students to carry out. Useful expressions part contains the linguistic information, primarily expressions and phrases that will facilitate the acting out of the roles. Celce-Murcia (1991) studied the classroom activities that make learners improve their communication skills and collected them under four rudiment directions to get better exchange:

a) Linguistically Structured Activities: These activities generally rotate around the performance or the practice of precise linguistic structures. What Celce-Murcia suggests is that though these activities are not deterring, they appear to be so if not contextualized and had an important effect.

b) Performance Activities: Activities in which students arrange something earlier to carry to their classes, following a classroom discussion. According to Celce-Murcia (1991), role-plays and dramas are outstanding examples of performance activities.

c) Participation Activities: In partaking activities, students cooperate in some communicative activities in natural sets. Conducted discussions, dialogs, and oral interchanges demonstrate these types of activities. At this point, the issue of authenticity rouses awareness and incentive on the part of the learners, calling for a natural need to do what is likely by the activity.

d) Observation Activities: In observation activities, learners probably observe, and record 
spoken and nonverbal exchanges between two or more native speakers of the target language. That has supreme benefit when students appreciate and become aware of the target language as they truly use it in real social settings.

Burgess and Etherington (2002) agree that to be authentic, texts should not be arranged for language teaching, but must be authentic samples of texts appearing unsurprisingly in normal contexts. Many communicative programs were planned to develop learners' communicative competence as defined by Canale and Swain (1980). These communicative programs propose many activities and tasks that engage the learner to figure out, employing, making, or interacting in the new language while attention is mainly concentrated on meaning rather than linguistic construction. (Nunan 2003, Nobuyoshi and Ellis 1997). The focus is on meaning; there is a goal to be accomplished which addresses a relationship between the task and real-life situations (e.g. Shopping, travelling, etc.). The Interaction Hypothesis (Long 1985, Nobuyoshi and Ellis 1993) states that learners acquire the new linguistic form by negotiating for meaning with a teacher or a peer to make the input graspable. For example, a learner who does not apprehend the lexical form "wear" asks one of his partners about it, who in turn provides him with the phrase "to put on clothes" to explain an aspect of the meaning in a definite context. Meaning-focused instruction endeavors to involve learners in communicative interactions in the L2 with a view to understanding and communicating meaningful communications (Ellis, 2003). Though, it has been argued that meaning-focused instruction, though efficient in evolving fluent oral communication skills, does not result in a high level of linguistic or sociolinguistic competence (Ellis, 2003), and that form-focused instruction should therefore be integrated with communicative classroom contexts. This paved the way to the progress of programs that focus on to L2 form in meaningful contexts.

\subsection{Form-Focused Instruction}

Spada (1997) describes form-focused instruction as pedagogical incidents which happen within meaning-based approaches to L2 instruction but in which an attention on language is presented in either extemporaneous or prearranged ways. In other words, the attention paid to form arises from a communicative need in response to which learners discover for themselves what the correct form is to make their meaning clear by using requests for clarification and confirmation. The relevant linguistic elements include phonological, lexical, grammatical, and pragma linguistic aspects of language (Ellis, 2001). By cultivating these linguistic elements, the teacher will attend to different forms in a lesson.

\subsection{Incidental Focus on Form}

Incidental focus-on-form refers to drawing learners' attention to the linguistic features that arise occasionally during task-based activities in lessons that focus mainly on communication or meaning conveyance. Incidental attention to form does not predetermine what kinds of form should be taught. Instead, the forms emerge from the communicative tasks performed in L2 classrooms. Incidental focus-on-form is characterized by extensive use of a variety of forms in the lesson as they arise from a communicative need (Ellis, 2001). In pre-emptive incidental focus-on-form, the teacher, or learners, choose specific forms to be the incidents of classroom discourse during meaning-focused classroom activities. Pre-emptive incidental focus-on-form is exemplified in some words that are synonymous with different uses that confuse L2 learners, such as stay and live. (Chinodya, 1992). 


\subsection{Planned Focus on Form}

Planned focus-on-form refers to teaching specific L2 forms that hamper L2 learners' speaking or writing in a structured fashion. It is characterized by drawing learners' attention to specific forms in a single lesson (Ellis, 2003). For example, the syllabus centers on planned practicing of specific linguistic features of the target language to help learners convey messages, as when to use comparatives such as very, extremely, so ... that, too ... for, etc., in different situations (Chinodya 1992). These forms are integrated throughout the learning units in the textbooks and aim to develop the correct and appropriate use of the L2. Research has shown the benefit of teaching specific linguistic features in a communicative context (Ellis, 2003). Rao's study (2002) also suggests that both communicative and non-communicative activities in ESL are beneficial to ESL classrooms. In conclusion, form-focused instruction is vital to enable learners to develop fluency and accuracy in ESL. It also helps to produce coherent spoken and written texts. Further, it helps ESL learners to learn the forms of ESL through incidental and planned ways of teaching. It facilitates the development of a high level of ESL linguistic, discourse and strategic competencies.

\subsection{Error Correction}

Errors are inevitable when learning a language and evolving communicative competence. In a study by Brown (2001) an error is described as a perceptible nonconformity from the adult grammar of a native speaker that reproduces the competence of the learner. Error reveals the level of L2 learners' competence. There are many reasons for learners' error: L1 intervention, insufficient L2 knowledge, complication of the L2, overgeneralization, and many psycholinguistic, perceptive, and affecting changeable. Learners' awareness of errors is generally brought by partners and teachers in interaction (Pica, 1994). Correcting and recognizing errors lead to outstanding communicative competence. Studies by Lightbown and Spada (1990) state that instantaneous feedback through classroom interaction improves accuracy. Lightbown (1990) assures that immediate modification form extensive and permanent recognition of errors and proper utilization of related forms. Pioneers of CLT approach consider errors as part of L2 natural education procedure, consequently, they are allowed as a positive sign of hypothesis-formation (Richards and Rodgers, 1986.) Priority of error correction should be given to errors that debilitate communication, as the objective is to improve learners' communicative fluency. Incidental and planned focus-on-form instruction aim to help L2 learners correct their errors in a feedback process during communicative activities and tasks. (Brown, 2001)

\section{Methodology of the Study}

In this study, a qualitative method of data collection to collect data from the respondents has been used. A questionnaire is built to elicit students' perceptions' toward CLT approach. Participants of the study are 101 university students in Dawadmi city, KSA, that have completed two levels of English language syllabus. Students are aged between 18 and 21 years old. In this study, only university students who are more proficient to implement CLT in class, are involved in the questionnaire to extract perceptions toward practices of CLT.

\subsection{The Questionnaire}

Students' questionnaire contains thirty statements testing three hypotheses that are concerned 
with communication and principles of communicative language teaching approach. All statements of the questionnaire are designed to answer these questions:

1. Do students believe that CLT is practiced in lectures?

2. How far are students aware of their teachers' classroom practices?

3. Do students' perceptions match their teachers' views about their practices?

4. What problems in practicing CLT are highlighted by students and teachers?

The first ten questions are formed to examine the importance of communication for students. Each of the ten statements tests the following hypothesis: Of the four language skills, the sample population perceives communication to be the most important, as it allows them to express themselves with locals and native speakers.

The second twenty statements are formed to see how teachers are able to apply tenets of CLT and whether CLT is an ideal approach for teaching English language. Statements are testing the following two hypotheses:

1) Likewise, the sample population perceives the communicative language teaching to be the ideal approach to teaching English. Teachers practically reflect this perception in their classroom practices and textbook choices that aim to enhance communication.

2) students believe that teachers attempt to put the tenets of communicative language teaching to practice. This includes, among others, emphasizing the students' fluency, stimulation of group interaction, minimal teacher's interference, dynamic seating position and encouraging learners' autonomy. Students should choose from responses of a Likert scale questionnaire:

\section{Strongly disagree. 2. Disagree. 3. Neutral. 4. Agree. 5. Strongly agree}

\subsection{Subjects of the Study}

Students involved in the study are Saudi university students. For the most part, students of the preparatory program in Shaqra university, all of them are Saudi students aging between 18 and 21 years old. Their exposition to the study of English language based on the educational system of Saudi Arabia that start teaching English language in the sixth grade of the elementary stage. The students have spent only six academic years receiving English language education. Students of the preparatory in Shaqra university are studying either medical sciences, medicine, or pharmaceutical sciences.

\section{3 procedures}

The data in the present study is analyzed by using the Statistical Package for Social Sciences (SPSS). To perform this analysis statistical testing in SPSS is exploited to analyze data of students views about the research questions and hypotheses. Questionnaire of students', which is the main instruments for data collection, provide detailed ideas for SPSS to retrieve analytic tables including values of mean, std. deviation, median, chi-square test, degree of freedom and the p-value. These values are supposed to help the researcher decide the most 
accepted hypothesis and help getting an image of findings and recommendations.

\section{Discussion}

This section describes the statistical analysis of the data collected from respond of student's questionnaire in addition to the interpretation and discussion of the results aiming to achieve the objectives of the study which concentrates on student's perception toward communicative language teaching. The data in the present study is analyzed by the Statistical Package for Social Sciences (SPSS). To perform this, a Chi-Square test is used to bring to light the inclusive responses of the students and teachers in their questionnaires and to measure up the different means of the responses in all questionnaires.

\subsection{Students responses eliciting perceptions toward practices of CLT approach.}

The researcher presumes that students perceive communication to be the most important, as it allows them to express themselves with locals and native speakers. Besides, students are aware that teachers are implementing tenets of CLT. To check the researcher's assumptions about CLT as an ideal approach assisting students to express themselves with locals and native speakers, the charts, and diagrams below are extracted from the (SPSS) program to get an overall perception of student's responses.

Table 1. English is learnt most effectively when it is used as a vehicle for doing something such as greeting, requesting, giving, and apologizing.

\begin{tabular}{|l|c|c|}
\hline & Frequency & Percent \\
\hline Strongly Agree & 62 & 61.4 \\
\hline Agree & 28 & 27.7 \\
\hline Neutral & 9 & 8.9 \\
\hline Disagree & 0 & 0 \\
\hline Strongly Disagree & 2 & 2.0 \\
\hline Total & 101 & 100.0 \\
\hline
\end{tabular}

The chart above shows that the majority of the students (62 students) strongly believe that English is learnt most effectively when it is used as a vehicle for doing something such as greeting, requesting, giving, and apologizing. Language is acquired by way of communication (Howatt, 1984). I.e. Learners are not exposed to the structural properties of the language to know it, but learners discover the system of the language when learning how to communicate in a language. Students perceive communication to be the most important among the four skills of English language. 


\section{Macrothink}

Table 2. Extensive reading is the best way to improve the overall command of English.

\begin{tabular}{|l|c|c|}
\hline & Frequency & Percent \\
\hline Strongly Agree & 47 & 46.5 \\
\hline Agree & 31 & 30.7 \\
\hline Neutral & 21 & 20.8 \\
\hline Disagree & 2 & 2.0 \\
\hline Strongly Disagree & 0 & 0 \\
\hline Total & 101 & 100.0 \\
\hline
\end{tabular}

The chart above shows that most of the students (47 students) strongly believe that extensive reading is the best way to improve the overall command of English. The researcher believes that students agree with the statement above because the act of only communicating in classroom does not extend knowledge of vocabulary, grammar, usage, and discourse; learners need further reading that help improve the overall command of English.

Table 3. The main goal of learning English should be communication.

\begin{tabular}{|l|c|c|}
\hline & Frequency & Percent \\
\hline Strongly Agree & 54 & 53.5 \\
\hline Agree & 26 & 25.7 \\
\hline Neutral & 18 & 17.8 \\
\hline Disagree & 2 & 2.0 \\
\hline Strongly Disagree & 1 & 1.0 \\
\hline Total & 101 & 100.0 \\
\hline
\end{tabular}

The researcher put this statement in student's questionnaire to see whether students' main goal of studying English language is communication or not and it is clear from the chart above students believe that communication is their main objective in learning English language.

Table 4. Being able to communicate easily with native speakers should be the primary goal of ELT.

\begin{tabular}{|l|c|c|}
\hline & Frequency & Percent \\
\hline Strongly Agree & 51 & 50.5 \\
\hline Agree & 26 & 25.7 \\
\hline Neutral & 22 & 21.8 \\
\hline Disagree & 2 & 2.0 \\
\hline Strongly Disagree & 0 & 0 \\
\hline Total & 101 & 100.0 \\
\hline
\end{tabular}

The highest frequency in the chart above reveals the student's strong agreement with the statement: being able to communicate easily with native speakers should be the primary goal of English language teaching. The statement above is the main goal of CLT approach and depicts the hypothesis of the present study. There are 22 students from the sample population of the students who are neutral and a nil value for students who strongly disagree with the 
statement.

Table 5. Reading the classical of English literature should be a compulsory part of English language syllabi.

\begin{tabular}{|l|c|c|}
\hline & Frequency & Percent \\
\hline Strongly Agree & 23 & 22.8 \\
\hline Agree & 23 & 22.8 \\
\hline Neutral & 30 & 29.7 \\
\hline Disagree & 20 & 19.8 \\
\hline Strongly Disagree & 5 & 5.0 \\
\hline Total & 101 & 100.0 \\
\hline
\end{tabular}

$45.6 \%$ of the students in the chart above agree with the statement: 'Reading the classical of English literature should be a compulsory part of English language syllabi', 29.7 of the students are neutral, 19.8 disagree and $5 \%$ strongly disagree with the statement above. The researcher includes this statement to see student's tendency toward reading but it seems clear from the chart that students do not like to neglect the reading skill as it allows them to enlarge their vocabulary and grammar knowledge.

Table 6. Writing is a more important skill than speaking.

\begin{tabular}{|l|c|c|}
\hline & Frequency & Percent \\
\hline Strongly Agree & 24 & 23.8 \\
\hline Agree & 14 & 13.9 \\
\hline Neutral & 22 & 21.8 \\
\hline Disagree & 28 & 27.7 \\
\hline Strongly Disagree & 13 & 12.9 \\
\hline Total & 101 & 100.0 \\
\hline
\end{tabular}

The chart above shows that 24 students strongly agree with the statement above. 14 students agree, 22 students are neutral, 28 students disagree, and 13 students strongly disagree with the statement that writing is the more important skill than speaking. It is clear that students have the same idea of the statement in table 5. The students do not neglect writing skill as it allows to practice vocabulary and grammar knowledge.

Table 7. Spoken fluency is a requirement for obtaining a well-paid job.

\begin{tabular}{|l|c|c|}
\hline & Frequency & Percent \\
\hline Strongly Agree & 39 & 38.6 \\
\hline Agree & 27 & 26.7 \\
\hline Neutral & 30 & 29.7 \\
\hline Disagree & 4 & 4.0 \\
\hline Strongly Disagree & 1 & 1.0 \\
\hline Total & 101 & 100.0 \\
\hline
\end{tabular}

The majority of the students believe that fluency is a requirement for obtaining a well-paid 


\section{Macrothink}

job. Speaking English fluently is an expected outcome of CLT approach. The chart shows that 39 students strongly agree, 27 students agree, and 30 students are neutral with the statement above. Four students disagree and only one student strongly disagrees with the statement.

Table 8. The main language problem of Saudi students is communication.

\begin{tabular}{|l|c|c|}
\hline & Frequency & Percent \\
\hline Strongly Agree & 46 & 45.5 \\
\hline Agree & 21 & 20.8 \\
\hline Neutral & 20 & 19.8 \\
\hline Disagree & 10 & 9.9 \\
\hline Strongly Disagree & 4 & 4.0 \\
\hline Total & 101 & 100.0 \\
\hline
\end{tabular}

The chart shows that 46 students, which are the majority, are strongly agree, 21 students agree, 20 are neutral, 10 are disagree and 4 students strongly disagree with the statement: The main language problem of Saudi students is communication. The researcher thinks that communication is a main problem of Saudi students because of the limited use of English for communication. There is an insufficient use of English language as a means of communication either in classroom or in public situations.

Table 9. Grammatical accuracy is more important than fluency.

\begin{tabular}{|l|c|c|}
\hline & Frequency & Percent \\
\hline Strongly Agree & 31 & 30.7 \\
\hline Agree & 21 & 20.8 \\
\hline Neutral & 18 & 17.8 \\
\hline Disagree & 18 & 17.8 \\
\hline Strongly Disagree & 13 & 12.9 \\
\hline Total & 101 & 100.0 \\
\hline
\end{tabular}

The statement above is a controversial issue among educationalist as CLT approach aim mainly in communication regardless of concentration on knowledge of the system of language. The researcher thinks that grammatical accuracy in a CLT classroom should not be completely neglected and students should get enlightenment about grammar of the language. The table above shows that 32 students believe that grammatical accuracy is more important than fluency and 21 students agree with the statement above. 19 students are neutral, 19 students disagree with the statement and only thirteen are strongly against the point above. The researcher thinks that the majority of the students agree with the statement above because of the system of examination that concentrates on the system of grammar knowledge of the language rather than communication skills. 


\section{MInstitute Macrothink $_{\text {Int }}$}

Table 10. A good knowledge of English does not necessarily imply the ability to communicate.

\begin{tabular}{|l|c|c|}
\hline & Frequency & Percent \\
\hline Strongly Agree & 10 & 9.9 \\
\hline Agree & 29 & 28.7 \\
\hline Neutral & 23 & 22.8 \\
\hline Disagree & 26 & 25.7 \\
\hline Strongly Disagree & 13 & 12.9 \\
\hline Total & 101 & 100.0 \\
\hline
\end{tabular}

The chart above shows that 10 students strongly believe that good knowledge of English does not necessarily imply the ability to communicate. 29 students agree with the statement and 23 students are neutral. There are 26 students who do not agree with the statement and 13 students strongly disagree with the statement above. The majority of the students disagree with the statement. The researcher thinks that some people might have good knowledge of language but fail to have the ability to communicate due to factors that relate to the speaker.

Table 11. The textbook "New Headway Academic Skills" stresses communication.

\begin{tabular}{|l|l|l|}
\hline & Frequency & Percent \\
\hline Strongly Agree & 19 & 18.8 \\
\hline Agree & 26 & 25.7 \\
\hline Neutral & 40 & 39.6 \\
\hline Disagree & 12 & 11.9 \\
\hline Strongly Disagree & 4 & 4.0 \\
\hline Total & 101 & 100.0 \\
\hline
\end{tabular}

The chart above examines whether the textbook that students studying meet the corresponds with the tenets of CLT approach. As it is seen in the chart above 19 students strongly believe that the textbook "New Headway Academic Skills" stresses communication. 26 students agree with the statement and 40 students are neutral. 12 students disagree and only four strongly disagree with the statement. The researcher thinks students textbook contains rich materials that students use for communication.

Table 12. The textbook employs authentic everyday language.

\begin{tabular}{|l|c|c|}
\hline & Frequency & Percent \\
\hline Strongly Agree & 27 & 26.7 \\
\hline Agree & 38 & 37.6 \\
\hline Neutral & 26 & 25.7 \\
\hline Disagree & 7 & 6.9 \\
\hline Strongly Disagree & 3 & 3.0 \\
\hline Total & 101 & 100.0 \\
\hline
\end{tabular}

Using authentic everyday language is a principle of CLT approach and the chart above shows that the majority of the students (27 students strongly agree, and 38 students agree) with the 
statement: the textbook employs authentic everyday language. 26 students are neutral,7 students disagree and only three students strongly disagree with the statement above.

Table 13. The material used in the textbook is relevant to the Saudi local environment.

\begin{tabular}{|l|c|c|}
\hline & Frequency & Percent \\
\hline Strongly Agree & 20 & 19.8 \\
\hline Agree & 32 & 31.7 \\
\hline Neutral & 28 & 27.7 \\
\hline Disagree & 10 & 9.9 \\
\hline Strongly Disagree & 11 & 10.9 \\
\hline Total & 101 & 100.0 \\
\hline
\end{tabular}

The chart above shows that the materials involved in the textbook are of interest to the students as 20 students strongly agree with the statement: the material used in the textbook is relevant to the Saudi local environment. 32 students agree with the statement and 28 students are neutral. There are 10 students who do not agree, and 11 students strongly disagree with the statement above.

Table 14. "New Headway Academic Skills" satisfies the communicative needs of medical students.

\begin{tabular}{|l|c|c|}
\hline & Frequency & Percent \\
\hline Strongly Agree & 30 & 29.7 \\
\hline Agree & 34 & 33.7 \\
\hline Neutral & 25 & 24.8 \\
\hline Disagree & 5 & 5.0 \\
\hline Strongly Disagree & 7 & 6.9 \\
\hline Total & 101 & 100.0 \\
\hline
\end{tabular}

Most of the sample of the students either medical sciences, medicine or pharmaceutical studies agree that the textbook satisfies the communicative needs of medical students. There are 30 students that strongly agree, 34 students agree with the statement above. The researcher agrees with the statement as a student's textbook contains rich materials that help students with their medical career.

Table 15. The textbook highlights speaking at the expense of reading and writing.

\begin{tabular}{|l|c|c|}
\hline & Frequency & Percent \\
\hline Strongly Agree & 20 & 19.8 \\
\hline Agree & 23 & 22.8 \\
\hline Neutral & 26 & 25.7 \\
\hline Disagree & 25 & 24.8 \\
\hline Strongly Disagree & 7 & 6.9 \\
\hline Total & 101 & 100.0 \\
\hline
\end{tabular}

The majority of the students agree with the statement: the textbook highlights speaking at the 
expense of reading and writing. There are 46 students who agree with the statement above. The researcher thinks that a student's textbook contains equal extract that satisfies student's need of English language knowledge involving the four language skills and students find sufficient practice for speaking, writing, reading, and listening skills.

Table 16. Memorization of grammatical rules is not an important component of New Headway Academic Skills.

\begin{tabular}{|l|c|c|}
\hline & Frequency & Percent \\
\hline Strongly Agree & 17 & 16.8 \\
\hline Agree & 21 & 20.8 \\
\hline Neutral & 21 & 20.8 \\
\hline Disagree & 21 & 20.8 \\
\hline Strongly Disagree & 21 & 20.8 \\
\hline Total & 101 & 100.0 \\
\hline
\end{tabular}

The chart above shows approximate equal frequencies for the statement: "memorization of grammatical rules is not an important component of New Headway Academic Skills". Students thinks the textbook does not explicitly introduce explanations for materials of grammatical rules but rather concentrates on communicative competence and building vocabulary.

Table 17. The textbook focuses on selected English contexts to raise the levels of learner's communicative competence in using English correctly and appropriately.

\begin{tabular}{|l|c|c|}
\hline & Frequency & Percent \\
\hline Strongly Agree & 26 & 25.7 \\
\hline Agree & 39 & 38.6 \\
\hline Neutral & 30 & 29.7 \\
\hline Disagree & 5 & 5.0 \\
\hline Strongly Disagree & 1 & 1.0 \\
\hline Total & 101 & 100.0 \\
\hline
\end{tabular}

The majority of the students agree with the statement: the textbook focuses on selected English contexts to raise the levels of learner's communicative competence in using English correctly and appropriately.

Table 18. This textbook has opened opportunities for me to improve my communication on my own.

\begin{tabular}{|l|c|c|}
\hline & Frequency & Percent \\
\hline Strongly Agree & 39 & 38.6 \\
\hline Agree & 27 & 26.7 \\
\hline Neutral & 23 & 22.8 \\
\hline Disagree & 11 & 10.9 \\
\hline Strongly Disagree & 1 & 1.0 \\
\hline Total & 101 & 100.0 \\
\hline
\end{tabular}




\section{Ml Macrothink}

The majority of the students strongly believe that the textbook has opened opportunities for them to improve their communication on their own. There are 39 students who strongly agree with this statement, 27 students agree with the statement above, 23 students are neutral, 11 disagree with the statement and only one student that strongly disagree with the statement above. The result of the statement above shows that students tend toward communication which is a tenet of CLT approach.

Table 19. This textbook instills confidence in learners that they visit English-speaking countries.

\begin{tabular}{|l|c|c|}
\hline & Frequency & Percent \\
\hline Strongly Agree & 42 & 41.6 \\
\hline Agree & 29 & 28.7 \\
\hline Neutral & 22 & 21.8 \\
\hline Disagree & 5 & 5.0 \\
\hline Strongly Disagree & 3 & 3.0 \\
\hline Total & 101 & 100.0 \\
\hline
\end{tabular}

The chart above shows that the majority of the students strongly believe the textbook instills confidence in learners when visiting English-speaking countries. There are 42 students who strongly agree with the statement above. 29 students agree, 22 are neutral, 5 students disagree and only three students who strongly disagree with the statement above.

Table 20. The textbook includes varieties and registers of English.

\begin{tabular}{|l|c|c|}
\hline & Frequency & Percent \\
\hline Strongly Agree & 30 & 29.7 \\
\hline Agree & 27 & 26.7 \\
\hline Neutral & 20 & 19.8 \\
\hline Disagree & 16 & 15.8 \\
\hline Strongly Disagree & 8 & 7.9 \\
\hline Total & 101 & 100.0 \\
\hline
\end{tabular}

Most of the students strongly agree with the statement: the textbook includes varieties and registers of English (e.g. formal and informal) that are appropriate to a variety of situations and purposes. The chart above shows that 30 students strongly agree with the statement above and 27 students that agree with the statement. There are 20 students who are neutral, 16 students that disagree and 8 students who strongly disagree with the statement above. 


\section{Macrothink}

Table 21. The teacher emphasizes communication in the classroom.

\begin{tabular}{|l|c|c|}
\hline & Frequency & Percent \\
\hline Strongly Agree & 45 & 44.6 \\
\hline Agree & 26 & 25.7 \\
\hline Neutral & 23 & 22.8 \\
\hline Disagree & 6 & 5.9 \\
\hline Strongly Disagree & 1 & 1.0 \\
\hline Total & 101 & 100.0 \\
\hline
\end{tabular}

The chart above shows that most of the students strongly agree with the statement: the teacher emphasizes communication in the classroom.

Table 22. The teacher spends much time explaining grammatical rules.

\begin{tabular}{|l|c|c|}
\hline & Frequency & Percent \\
\hline Strongly Agree & 34 & 33.7 \\
\hline Agree & 25 & 24.8 \\
\hline Neutral & 25 & 24.8 \\
\hline Disagree & 14 & 13.9 \\
\hline Strongly Disagree & 3 & 3.0 \\
\hline Total & 101 & 100.0 \\
\hline
\end{tabular}

The researcher puts the statement above in students' questionnaire to make sure that teachers are implementing tenets of CLT approach, but student's responses show that some of the teachers are following traditional methods of teaching, spending much time explaining grammatical rules. The chart shows that most of the students agree with the statement: teacher spends much time explaining grammatical rules. There are 34 students who strongly agree with the statement above and 25 students agree with the statement. The chart also shows that 25 students are neutral, and 14 students agree with the statement. There are only three students that strongly disagree with the statement above.

Table 23. The teacher dominates all the activities and is the only speaker throughout the lecture.

\begin{tabular}{|l|c|c|}
\hline & Frequency & Percent \\
\hline Strongly Agree & 39 & 38.6 \\
\hline Agree & 26 & 25.7 \\
\hline Neutral & 21 & 20.8 \\
\hline Disagree & 10 & 9.9 \\
\hline Strongly Disagree & 5 & 5.0 \\
\hline Total & 101 & 100.0 \\
\hline
\end{tabular}

The majority of the students in the chart above agree with the statement: the teacher dominates all the activities and is the only speaker throughout the lecture. If the teacher takes the dominant role in classroom discourse in terms of initiating the topic, allocating turns and evaluating comments, the student's role is only that of respondent and opportunities for 
developing the speaking skill are therefore severely limited.

\section{Conclusion}

Among the points that the researcher finds out and thought to be in concurrence among teachers and students is the fact that English is learnt most effectively when it is used as a vehicle for doing something, such as greeting, requesting, giving, apologizing. Another point of interest is that the main goal of learning English should be communication. Students responses in their questionnaire show that communication is their main objective in learning English language. Teachers support student's tendency to learn the language for communication and believe that students learn the language most successfully when it is considered as a social instrument for communication, not when it is in a form of explicit rules. The controversial issue on the practices and techniques of CLT is whether the grammatical accuracy is more important than fluency or fluency is more crucial. It is a controversial issue among educationalist because CLT approach aims mainly to communication regardless of concentration on knowledge of the system of language. The researcher believes that structural correction in a CLT classroom should not be entirely ignored and students should be corrected in situations that show communication failure.

\subsection{Findings}

Findings of the study are summarized in the following statements:

a) English is learnt most effectively when it is used as a vehicle for doing something such as greeting, requesting, giving, and apologizing.

b) Teachers perceive CLT to be the ideal approach to teaching English.

c) Being able to communicate easily with locals / native speakers should be the primary goal of English language teaching.

d) Teachers should put tenets of communicative language teaching into practice. The tenets include emphasis on students' fluency, stimulation of group interaction, minimal teachers' interference, dynamic seating position and encouraging learner's autonomy.

e) Teachers' efforts should focus on communicative content, not on linguistic form to make sure that learners become effective communicators in the foreign language.

\subsection{Recommendations}

Based on the research findings, the researcher recommends the followings:

a) Teachers had better employ communicative language teaching approach to enhance communication.

b) Students had better make communication main objective for learning a new language.

c) Teachers' efforts should focus on communicative content to make sure that learner become effective communicators in the foreign language. 


\section{MlMacrothink}

Journal of Studies in Education

ISSN 2162-6952 2020, Vol. 10, No. 2

d) The teacher uses conversations, role-plays, debates, and dialogues as the main form of teaching.

e) The teacher had better not amend learners' errors, except when these errors make communication a failure.

f) Traditional seating does not help students perform better. Teachers had better arrange the class in modular, horseshoe classroom seating positions and divide students into pairs and small groups when carrying out communicative activities.

\subsection{Suggestions for Further Studies}

The researcher recommends the following further fields of interest for potential PH. D students:

a) The present study was limited to students' perceptions toward communicative language teaching approach. A prospective PH. D student has an opportunity to investigate teachers' perception toward communicative language teaching approach.

b) The researcher touches areas of controversial issues concerning priority of grammatical accuracy to communicative accuracy when learning a new language. Thus, an investigation of such controversial issues is available for researching.

\section{References}

Brown, H. D. (2001). Teaching by principles: An Interactive approach to language pedagogy. New York: Addison Wesley Longman, Inc.

Burgess, J. and Etherington, S. (2002). Focus on grammatical form: explicit or implicit? Cambridge University Press. https://doi.org/10.1016/S0346-251X(02)00048-9

Canale, M., \& Swain, M. (1980). Theoretical bases of communicative approaches to second language teaching and testing. Applied Linguistics. https://doi.org/10.1093/applin/I.1.1

Celce-Murcia, M. ed. (1991). Teaching English as a Second of Foreign Language, 2nd ed. Boston: Heinle \& Heinle.

Chinodya, S. (1992). Step Ahead New Secondary English: Students' Book 2. Longman Zimbabwe.

Day, E., \& Shapson, S. (1991) Integrating formal and functional approaches to language teaching in French immersion: An experimental study. Language Learning. https://doi.org/10.1111/j.1467-1770.1991.tb00675.x

Ellis, R. (1997). SLA Research and Language Teaching. Oxford: Oxford University Press.

Ellis, R. (2003). Task-based language learning and teaching. New York: Oxford University Press.

Ellis, R., Basturkmen, H., \& Loewen, S. (2002). Doing focus-on-form. System, 30. https://doi.org/10.1016/S0346-251X(02)00047-7 


\section{Mll Macrothink}

Journal of Studies in Education

ISSN 2162-6952 2020, Vol. 10, No. 2

Ellis, R., Basturkmen, H., \& Loewen, S. Autumn (2001). Preemptive focus on form in the ESL classroom. TESOL Quarterly. https://doi.org/10.2307/3588029

Larsen Freeman, D. (2001). Techniques and principles in language teaching. New York.

Lightbown, P. M., \& Spada, N. (1990). Focus-on-form and corrective feedback in Communicative language teaching: Effects on second language learning. Studies in Second Language Acquisition. https://doi.org/10.1017/S0272263100009517

Long, M. H. \& P. A. Porter. (1985). Group Work, Interlanguage Talk, and Second Language Acquisition. https://doi.org/10.2307/3586827

Lyster, R., \& Ranta, L. (1997). Corrective feedback and learner uptake: Negotiation of form in communicative classrooms. Studies in Second Language Acquisition. https://doi.org/10.1017/S0272263197001034

Nobuyoshi, J., \& Ellis, R. (1993) Focused communication tasks and second language acquisition. ELT Journal. https://doi.org/10.1093/elt/47.3.203

Nunan. (2003). Task based learning and teaching. Cambridge university press. https://doi.org/10.1017/CBO9780511667336

Paulston, C. B., \& Bruder, M. N. (1976). Teaching English as a second language: Techniques and procedures. Cambridge, MA: Winthrop

Pica, T. (1994). Questions from the language classroom: research perspectives. TESOL Quarterly. https://doi.org/10.2307/3587198

Rao, Z. (2002). Chinese students' perceptions of communicative and non-communicative activities in EFL classroom. https://doi.org/10.1016/S0346-251X(01)00050-1

Richards, J .C, \& Rodgers, T.S. (1986). Approaches and methods in language teaching. Cambridge: Cambridge University Press.

Spada, N. (1997). Form-focused instruction and second language acquisition: A review of classroom and laboratory research. Language Teaching. https://doi.org/10.1017/S0261444800012799

\section{Appendix}

Student's Questionnaire

\begin{tabular}{|l|l|l|l|l|l|l|}
\hline No. & Statement & SD & D & A & SA \\
\hline 1 & $\begin{array}{l}\text { English is learnt most effectively when it is used as a vehicle for } \\
\text { doing something such as greeting, requesting, giving, and } \\
\text { apologizing. }\end{array}$ & $\begin{array}{l}\text { Extensive reading is the best way to improve the overall } \\
\text { command of English. }\end{array}$ & & & \\
\hline 3 & The main goal of learning English should be communication. & & & & \\
\hline 4 & Being able to communicate easily with native speakers should & & & \\
\hline
\end{tabular}




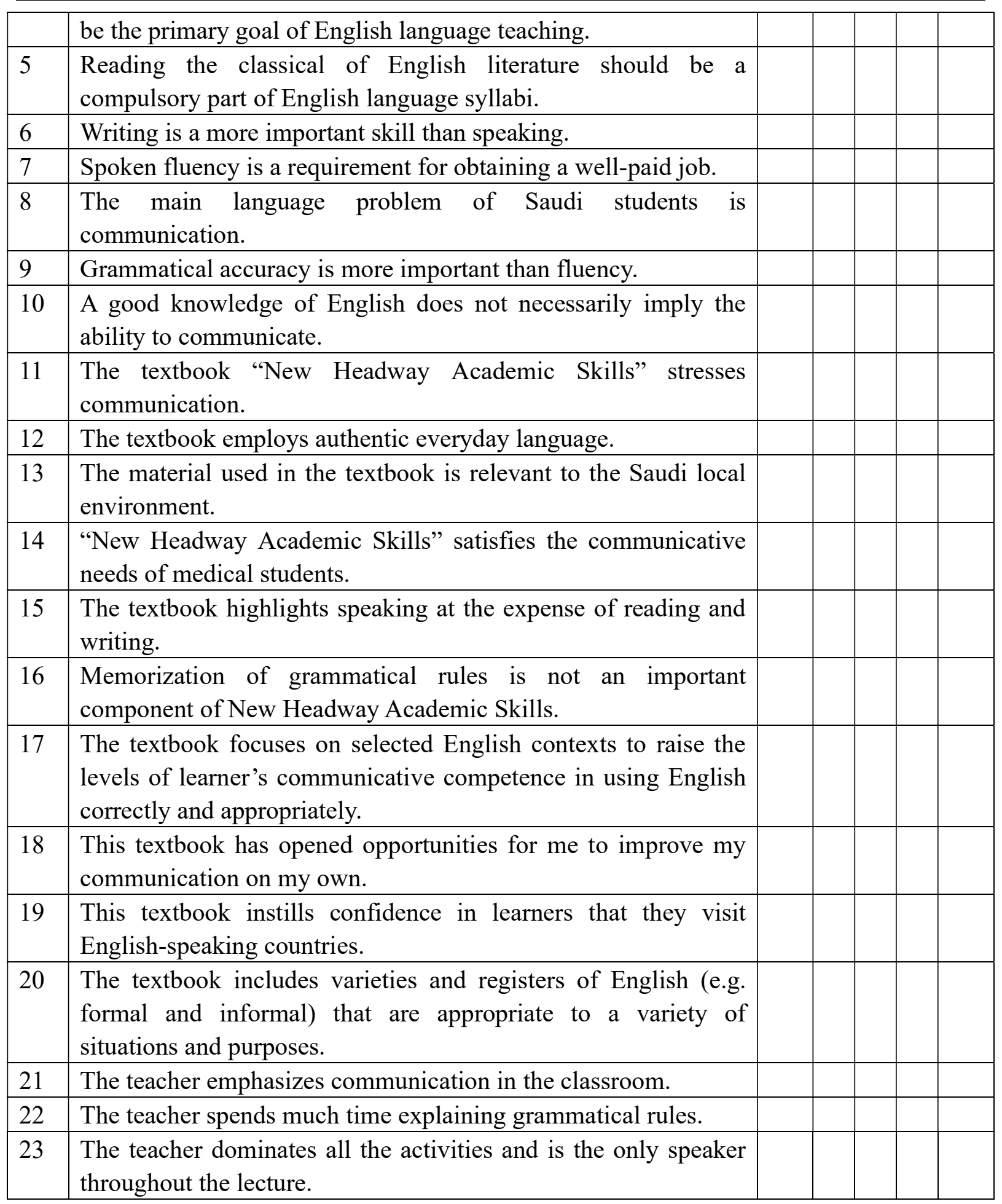

